
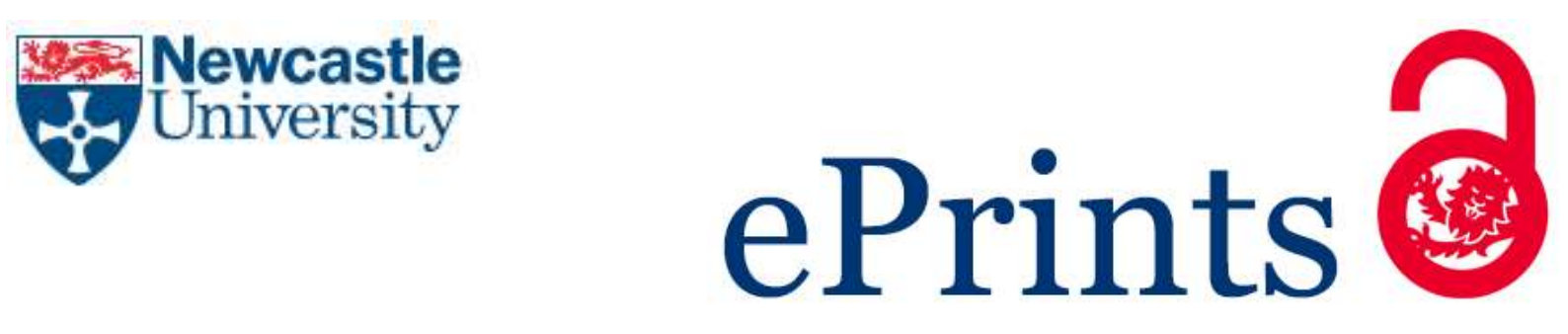

Richards J. Reading and Listening to William Baldwin. In: Archer, H; Hadfield, A, ed. A Mirror for Magistrates in Context: Literature, History and Politics in Early Modern England. Cambridge, UK: Cambridge University Press, 2016, pp.71-88.

\title{
Copyright:
}

This material has been published in A Mirror for Magistrates in Context: Literature, History and Politics in Early Modern England by / edited by Archer, $\mathrm{H}$; Hadfield, A, ed. This version is free to view and download for personal use only. Not for re-distribution, re-sale or use in derivative works. (C) Cambridge University Press

Link to published book:

http://www.cambridge.org/gb/academic/subjects/literature/renaissance-and-earlymodern-literature/mirror-magistrates-context-literature-history-and-politics-early-modernengland?format $=\mathrm{HB}$

Date deposited:

$03 / 10 / 2016$

Embargo release date:

01 February 2017

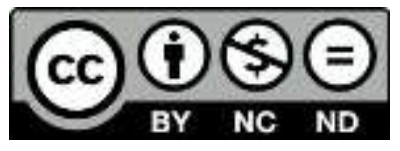

This work is licensed under a

Creative Commons Attribution-NonCommercial-NoDerivatives 4.0 International licence 


\section{Reading and Listening to William Baldwin}

Jennifer Richards

William Baldwin is a man of a mystery. It is easier to say what we don't know about him than what we do. We don't know when he was born, nor are we sure when he died: 'in or before $1563^{\prime}$, says the entry in the $O D N B .{ }^{1}$ We don't know where he was from, although it is possible that he was of Welsh descent. We don't know where he went to school; nor do we know if he went to university. 'Baldwin may have supplicated the regents of Oxford University in 1533 for a degree and entered service as a schoolmaster', says John N. King, although he quickly adds that 'this too cannot be confirmed'.

Yet, the few things we do know about him have been enough for Scott C. Lucas to build a picture of the literary strategies of this most popular of mid-Tudor writers. We know, for instance, that he worked as a corrector for the Reformation printer Edward Whitchurch who, with Richard Grafton, oversaw the publication of the Matthews Bible (Antwerp, 1537) and the printing of the first edition of the Great Bible (1539) and the first editions of The Book of Common Prayer $(1549 ; 1552)$, as well as ABCs and catechisms for children. ${ }^{3}$ We also know that when Whitchurch retired, perhaps to avoid persecution under Mary I in 1553 as Lucas proposes, that Baldwin continued to work in the same shop for its new owner, 'a scrivener named John Wayland, a religious conservative who enjoyed the favour of Mary's government'. ${ }^{4}$ We know this if we read Baldwin's account of the origins of this work in one of the prefaces, 'A Briefe Memorial of sundrye Unfortunate Englishe men', to his best known print-publication, A Myrroure for Magistrates (1559), alongside John Wayland's note on his publishing plans, 'The Prynter to the Reader', in John Lydgate's translation of The fall of prynces (1554), to which the original Myrroure was meant to be appended. ${ }^{5}$ 
Baldwin's professional life during a decade of political and religious turmoil, the 1550s, goes some way to explain the difficulties of the Myrroure, a text which, as Lucas rightly observes, has been all but abandoned by literary critics who find it lacks a clear sense of purpose. ${ }^{6}$ Indeed, the Myrroure is a complex work. For a start, the 1559 edition, to which I turn at the end of this chapter, has two prefaces, likely written by Baldwin at different times, and these orientate the reader in different ways. The first is dedicated 'To the nobilitye and all other in office', and it makes the Myrroure a work of admonition, leading with a memorable moral-political saying, which is marked with inverted commas (diples) in the margin: 'Well is that realme governed, in which the ambicious desyer not to beare office'. ${ }^{7}$ The second, titled 'A Briefe Memorial', perhaps surviving from the suppressed earlier edition (1554-5), emphasises instead that this is a 'multivocal collection' ${ }^{8}$ Each one of its nineteen tragedies is spoken in the first person by a different fallen 'magistrate', composed by one of seven collaborators. One of these collaborators is already known to us: Baldwin. The only other collaborator who is named in this preface is George Ferrers, and he is quoted at length proposing that they should begin where John Lydgate's The fall of prynces left off, 'whiche was about the ende of king Edwarde the thirdes raigne'. ${ }^{9}$ Other names are revealed in later editions, including Thomas Chaloner, the translator in 1549 of Erasmus's mock-oration, Moriae Encomium, and the author of Richard II's narration, which I will discuss later.

Lucas offers one way of making sense of this 'multivocality'. The sympathies of Baldwin, an 'evangelical editor', he explains, lie with Whitchurch who was 'a leading producer of evangelical literature' during the reign of the King Edward VI (1547-1553). ${ }^{10}$ His convictions, he proposes, were unknown to the more conservative Wayland, although they were apparently known to Stephen Gardiner, who suppressed the first edition of a Myrroure, titled A Memorial of suche Princes, as since the tyme of kyng Richard the seconde, have been unfortunate in the Realme of Englande (c. 1554-55). It is during this difficult period, Lucas 
surmises, that Baldwin learned how to become a covert controversialist. He established 'two contexts for reading the Memorial tragedies, one overt but actually deflecting and misleading, and the second much less widely interpretable but highly significant for the intended audience to whom it spoke'. In short, Baldwin sought to mislead Marian magistrates while communicating to evangelical readers his commitment to the " godly" ideals of Edward VI's reign and 'his support for free expression of potentially uncomfortable political commentary in print'. ${ }^{11}$

Literary scholars have long acknowledged Baldwin's confessional identity, and there is convincing evidence to suggest that he became a minister in or shortly before $1559 .{ }^{12}$ It is also clear that the Myrroure is a political work, although in what way is less obvious because the two prefaces point us in different directions. ${ }^{13}$ Lucas has done more than any other recent scholar to try to think through Baldwin's possible religio-political allegiances, and his insights are suggestive. The claim that Mary I's judiciary is being covertly criticised in the first tragedy of Robert Tresilian by Ferrers seems right to me. ${ }^{14}$ He also makes an interesting case to support the idea that the tragedy of 'Humfrey Duke of Gloucester', intended for the 1554 edition but not printed until 1578, was meant to reflect on the protestant hero Edward Seymour, Duke of Somerset. ${ }^{15}$ Yet, all the same, there are a few additional details we could add to our portrait of Baldwin to inform our reading of his work, including of the Myrroure. Indeed, there is one other verifiable detail, the likelihood that Baldwin was employed as an actor, a deviser of entertainments and a prop maker at court during the Christmas season of 1552/3 under the Master of the King's Pastimes, Ferrers. This detail is documented in the Revels Accounts for this Christmas period, and it is also written into Baldwin's antiCatholic fiction, Beware the Cat $(1570 ; 1584 ; \mathrm{ms} .1553)$. Its preface explains the 'real' context for this fabulous tale thus: 'Baldwin' (G.B. in the text) and Ferrers heard the tale from Master Streamer while they were organising Christmas interludes for King Edward VI. ${ }^{16}$ 
Might this detail lead us to a simpler explanation of the Myrrour's multivocality? I suggest that it would; it reveals a Baldwin who is more playful and more knowledgeable about rhetorical affect than does the one-dimensional version of him as an underground reformer.

There is more that we might add to flesh out this portrait. It is not known if Baldwin went to university but he certainly would have gone to grammar school, and it is there that he would have learned his craft both as a writer and a performer of multivocal texts. Education in the Renaissance, like the medieval period, was oral. We might do well to imagine Baldwin engaging in the reading activities designed to help him become a fluent reader, writer and speaker of Latin: matching emotions to types of voice; varying the intonation and the meaning of Latin sentences as he pronounced them; uttering 'every dialogue' that he was asked to read - whether by Aesop, Terence or Virgil - in a 'lively' fashion as if he 'were the persons which did speake in that dialogue'. We might also imagine him putting this knowledge to use in Latin written exercises like 'prosopopoeia', 'a certaine Oracion made by voice, and lamentable imitacion, upon the state of any one', which he may also have been asked to perform 'as if ex animo in good earnest, with all contention and vehemencie'.17 Finally, we might imagine him honing these skills in English outside the schoolroom not just in the entertainments organised by Ferrers, but also in Whitchurch's print shop, one of the places, I have already noted, where the performance scripts for the new liturgy were printed. As a corrector he would have read these texts aloud as they were prepared for the press. ${ }^{18}$ And as a reformer, he would have welcomed the Prayer book's new emphasis on listening and understanding. For too many years, Thomas Cranmer complained in its preface, the church service in England was read in Latin so that the people 'heard with their ears only: and their hearts, spirit and mind have not been edified thereby'. ${ }^{19}$ Baldwin's interest in performance would have carried over to secular works too. Since he was employed by Wayland in 1554, he likely also read aloud some of Lydgate's The fall of prynces. If he did, 
he surely would have noted the effect of the tragic narrations on the poet who penned them. In the final narration, the historical moment at which Baldwin's Myrroure takes over, we read that King John of France tells the tale of his defeat by King Edward III to 'Bochas', as well as Lydgate's comment on this. The latter thinks Boccaccio has shown too much 'affection', overlooking John's faults: 'Of right witnesse every croniculer/ Should in his writying make no exception,/ Indifferently convey his matter/Nor be perciall of none affection' ${ }^{20}$

I sketch out this particular soundscape of Baldwin's day-to-day to take more account of a feature of his writing to which he so insistently draws our attention, and which we just as insistently ignore: its vocality. By ‘vocality' I don't mean only that Baldwin is experimenting with the speaking voice in writing. Rather, I mean that he imagines the effect of writing when it is enlivened by the speaking voice. Baldwin foregrounds this in the Myrroure in the frame between the tragedies in which the collaborators are represented responding to the tales they have heard. It is not that this feature is ignored but it is not sufficiently noted. It should be the starting point of any reading of this text because it complicates how we make its moralpolitical content meaningful. ${ }^{21}$ To help to make this dramatic feature of the Myrroure more central to how we read it, I begin with one of Baldwin's earlier writings in which his concern with the voice cannot be ignored, Beware the Cat.

\section{The Visible Voice of Beware the Cat}

I am not the first to notice that William Baldwin is preoccupied in his fiction with reading as oral and aural as well as visual. We only have to recall the scene-setting of Beware the Cat to recognize 'the fluidity between aural and visual experiences of texts' for Baldwin. ${ }^{22}$ This oral tale is first told in a bedchamber. Four men, George Ferrers, his astronomer Mr Willot and divine, Master Gregory Streamer and G.B. [Gulielmus Baldwin] are at court at Christmas. 'Baldwin', and Ferrers have been employed to organize the Christmas interludes for the 
King. In a conversation with Streamer, 'Baldwin' makes clear his objection to one of the planned interludes, 'Esop's Crowe', dismissing the conceit because he does not think it is 'Comicall to make either speechlesse things to speeke: or brutish things to common reasonably'. Indeed, he goes further, arguing that it is 'uncomely ... to bring [animals] in lively parsonages to speake, doo, reason, and allege authorites out of authours'. Yet, Streamer holds 'the contrary parte', and he promises to share with the company the tale we are about to read: his encounter with cats who could speak. ${ }^{23}$

The tale 'Baldwin' transcribes is very odd. There is a rambling opening, which locates Streamer in a friend's house in St Martin's Lane and, more specifically, 'in a Chamber hard by the Printing house' where he is busy correcting the proofs of his 'Greeke Alphabets'. ${ }^{24}$ Streamer tells his companions at the fireside of the noise that cats are making outside his chamber at night-time. This prompts one of the company to tell an Irish tale of the death of the king of the cats, Grimalkin, and of the strange behaviour of one kitling when she heard the news. There are other tales that follow, all of which are considered as proof either that cats have reason or, on the contrary, that they can be bewitched. This discussion prompts Streamer to listen again later that night, noting the variation in the cats' miaows, and this leads him to prepare a magical potion to purge his ears so he can understand what they are saying. The potion is successful. It turns out that Streamer is right: the cats are communing with each other. They have gathered for the trial of Mouse-slayer who has refused to mate with Catch-rat, so breaking one of the holy laws of cats: that females are forbidden 'to refuse any males not exceeding the number of $\mathrm{x}$. in a night' ${ }^{25}$ In her defence, Mouse-slayer is required to declare her life since 'kitling hood' so her judges can 'perceive how I behaved me'. ${ }^{26}$

Odder still is the way the tale is shared with us. It is spoken by Streamer who is in turn recalling the stories told by many other incidental speakers, including Mouse-slayer. 
These tales have been transcribed by 'Baldwin' who aims to make the collection look more 'book like' by adding marginal glosses, prefatory material and a moralizing epigraph, and by organizing the rambling story into three parts or orations. ${ }^{27}$ If you happen to read it in William Ringler's and Michael Flachmann's modern spelling edition of 1988 - as most scholars do - rather than in the only surviving early print edition of 1584 , or the 1847 manuscript transcription of the now lost first edition of 1570 held in The British Library, then you read it through yet another editorial frame and set of assumptions. ${ }^{28}$ Add to this the fact that in the fiction the text is described as being in a state of revision: that is, the manuscript is being prepared for print. 'Baldwin' asks the dedicatee, John Young, to pass the manuscript to Streamer so he can 'peruse it before the printing, and amend it if in any point I have mistaken him' ${ }^{29}$ Rachel Stenner summarizes the position that the reader finds herself in thus: she is reading a 'still unprinted document, a manuscript representation of an oral tale, that has been sent to its originator for checking and correction before going to press', ${ }^{30}$

The interplay between these three different modes of communication - speech, writing, print - makes this a challenging work, and indeed it is hard to identify a clear line of argument. It is only recently, I would suggest, that we have recognised this. Beware the Cat, John N. King wrote confidently in 1982, is an attack on Catholicism and its 'oral traditions'. 'Baldwin's written texts', he argues, 'which are labelled by Streamer as "hearsay", are more tangible than the bewildering oral tradition' the latter offers 'by way of firsthand experience and "proof" that cats can talk. ${ }^{31}$ More than two decades later, though, it is accepted that Baldwin is challenging the authority of the written word as well, and that communication is his theme. Baldwin shows no confidence whatsoever, Thomas Betteridge argues, in the 'power' of writing or print to 'carry a radical reforming message throughout the country'. ${ }^{32}$ Meanwhile, Stenner suggests that 'writing by hand' is just as much one of this work's 'objects of satire': the handwritten text, she observes, can be put 'to suspect uses'. ${ }^{33}$ Jane 
Griffiths is a little more optimistic. She focusses on the marginal glosses, noting that though they appear to be 'a diligent printer's attempt to make his text more accessible to the reader', in fact they reveal 'Baldwin's' 'inability to discriminate'. The disjunction between text and gloss, however, is designed to make us independent and critical readers. ${ }^{34}$

All of these literary scholars, though, quietly assume a silent reader. In so doing, they overlook an additional complication: the possibility that the text - manuscript or print - is read aloud, or, if it is not actually read aloud, then that the reader projects aurally onto the text. ${ }^{35}$ The possibility either way is signalled in 'The Epistle Dedicatory'. 'Baldwin' acknowledges that he is aware that its dedicatee, John Young, had really wanted Ferrers to report the story to him, and he modestly recognizes that he cannot match his skill as a story teller. Still, he believes that he has represented Streamer's speaking voice in his prose, boasting that 'I dout not but that he and M[aster]. willot shal in the reading think they hear $\mathrm{M}$ [aster]. Streamer speak, and he him self in the like action[n], shal dout whether he speaketh or readeth' ${ }^{36}$ It is not just Streamer's voice, however, that we are being invited to 'hear', but the voices of the cats and many other shady characters. Meanwhile, 'Baldwin's' unease with prosopopoeia - the technical term for making 'speechlesse things to speeke' - is passed onto us.

The voice is one of the central themes of Beware the Cat. We are asked not just to read a series of oral tales and to imagine a sociable oral culture - gentlemen sitting at the fireside telling each other stories - but also to think about the 'voice' as a mode of communication and a means to interpretation. The catalyst for the story is the noise of cats on adjacent rooftops. Their miaowing is so melodious that Streamer is led to believe they are speaking to one another: 
they observed no Musicall cordes neither Diatessero[n], Diapente, nor Diapason, and yet I ween I lye, for one Cat groning as a Beare dooth, when Doges be let slip to him, throwled out so lowe and loud a base, that in comparison of an other Cat which crying like a yung Childe squeiled out the shriking treble: it mought be wel counted a double Diapason. $^{37}$

Streamer is intrigued. He finds a room with a window overlooking the rooftop so he can hear and see the cats. He identifies a large grey cat, 'the cheef', and a second cat (Mouse-slayer) who 'mewed continewally', declaring 'some matter'. 'I was straight caught with such a desire', he admits, 'to knowe what she had said: that I could not sleep of all that night, but lay devising by what meanes I might learn to understand them'. He decides to make a potion to clear his ears, and discovers a recipe in the section 'Si vis voces avium intelligere' (if you wish to understand the voices of birds) in Albertus Magnus's De virtutibus animalium. ${ }^{38}$

With the help of this recipe, he makes pills for his ears to sharpen his hearing so that he can distinguish between noise which, he explains, is created by the moving air of 'dead' things like 'windes, waters, trees, carts, falling of stones', and voices, which are the 'breth of living creatures'. ${ }^{39}$ These pills in turn embody the physical voice in several ways. The ingredients include the organs of voice and hearing, the 'tungs' and 'eares' of various animals ${ }^{40}$ the power of which has been released by the 'breath' of Streamer who says the following magic/nonsense words aloud as he kills them: “"Shavol swashmeth, gorgona liscud"'. ${ }^{41}$ Streamer explains that he then 'fryde' the pellets 'in good oyle olife' - a detail I always enjoy - 'and layd the $[\mathrm{m}]$ hot to mine eares', keeping them in place 'til nine a clock at night, which holpe exceedingly to comfort my understanding power'.$^{42}$ He immediately hears 'a loud voice' crying 'what Isegrim', and rightly deduces that this is one of the cats speaking. ${ }^{43}$ Thereupon he is overwhelmed by the noises he can hear within a radius of one 
hundred miles until he has the good sense to stop his ears, at which point he can settle down to listen.

Baldwin is clearly sceptical of the power ascribed to the voice. Having Streamer pronounce the nonsense words "“Shavol swashmeth, gorgona liscud"' is not enough; 'Baldwin', the listening reader, must diligently add in the margin this superfluous note: 'Albertus saith if a man when he prepareth any Medicin tell alowde why he maketh it: it wil be of more force'. ${ }^{44}$ The satire no doubt is directed at Catholicism and its 'oral traditions', just as King proposed. The bawd's tale - and the tales related in the first oration - are reminiscent of late medieval stories that attribute supernatural properties to voice, like the 'well known tale of a mother', recalled by C. M. Woolgar, who carelessly cursed her daughter because she had displeased her. The mother's spoken words - 'De Deyvl com on be' - had 'a literal effect', Woolgar notes, 'her passion reflecting that of her soul, speaking directly to the Devil', who then spirited the daughter away. ${ }^{45}$ Yet, Baldwin's object of satire is not only medieval or Catholic oral traditions. We should remember that the anti-Catholic pronouncements in Beware the Cat, of which there are many, are made by a fool, Streamer, and his naïve auditor, 'Baldwin'; and we should also recall that the attribution of special powers to the voice had its Reformation equivalents. Defenders of the established church like Richard Hooker would eventually complain that the puritans set too much store by 'accidentals': voice and gesture. ${ }^{46}$

Baldwin's awareness of the voice, I suggested earlier, would have been a product of his training, his working life and his protestantism. We need to take account of the fact that he would have been trained to think about vocal affect at school, and that he was committed both as a reformer and printer to the production of texts that understood that salvation was dependent on aural comprehension. Yet the voice is a tricky means to comprehension not just because of the risk of mishearing but also because it communicates emotion. One of the ways 
that Baldwin alerts us to this latter danger - and trains us to be discriminating listening readers - is by exploring the effects of prosopopoiea on the reader inside and outside his fiction.

Prosopopoeia, the 'speaking figure' as Gavin Alexander calls it, helps us to understand 'the creation of character', and it involves, at its most basic, 'a simple trick of grammar that personifies something inanimate' ${ }^{47}$ It's a useful term for literary scholars to know because it helps us to distinguish clearly between the author and persona when we are reading. Yet, prosopopoeia is also a figure of address, one that 'happens', Gavin Alexander acknowledges, citing Quintilian, 'when readers perform the voices that writers have created' ${ }^{48}$ (On this view, all reading aloud in the first person is prosopopoeia.) The figure is the same but the focus is now on the reader, not the author, and on the act of voicing rather than silent reading. The effect of the figure also changes. When someone - a real reader or a character in a text - performs the voice of a character created by a writer, the relationship between the persona and the speaker (or singer) is blurred. Often this blurring is usefully revealing. So Alexander cites the example of Desdemona singing the words of the jilted maid Barbary in Shakespeare's Othello: “"The poor soul sat sighing by a sycamore tree"'. When she sings these words she identifies with the maid. Here, the "possibility of sharing emotion and experience', Alexander argues, is 'both therapeutic and heuristic; the performer discovers something about herself by comparing her identity to that of another, and by putting on a mask is able to express herself more eloquently than by remaining in her own person' ${ }^{49}$ Yet sometimes the blurring between speaker and persona is confusing, even troubling, for instance when the voice the reader breathes life into belongs to a shady narrator.

We are given a very good example of the dangers of prosopopoeia in Baldwin's third oration: Mouse-slayer's recollection of a double conversion, which Streamer over hears. The first is the transformation of a virtuous, married lady into a cat. This is an elaborate fiction 
told by a bawd - and recounted by Mouse-slayer - that succeeds in persuading another virtuous wife to 'to co[m]it whordome'. ${ }^{50}$ This second act of conversion involves several different kinds of performance and lots of tears to soften the lady's heart: the tears of the bawd who pretends that it her daughter who was turned into a cat; the weeping daughter-cat (Mouse-slayer, who has been fed a heavy dose of mustard, causing her to cry); and the tears of the lady once she has read a fake letter handed to her by the bawd. It is this letter, shared by the illiterate bawd, which breaks the lady's resolution so that she agrees to fulfil her own suitor's 'lust'.

I would suggest that to understand this moment of conversion - how it is that an unquestionably virtuous lady becomes a whore - we need to understand the letter not only as a literary artefact or document but also as an example of performed prosopopoeia that blurs the distinction between the reader (the lady) and the speaker (the fake rejected lover). The letter is an 'Oracion made by [the] voice' of the fake unrequited lover. Indeed, it represents his voice visibly, substituting for his physical presence. It is full of the 'aural' patterns that 'speak' to an addressee: 'Cursed be the woful time wherin mutuall loove first mixed the masse of my miserable carcasse. Curssed be the houre that ever the fatall destinies have ought for me purveyed. [....,${ }^{51}$ Meanwhile, the curse/prayer he pronounces is voiced outside the letter too. 'I besech (I say) the just Gods', he writes, 'that eyther they chaunge that honest stony hart or els disfigure that faire merciless favour'. Two days later a mysterious 'voice', the origin of which is uncertain, 'cried a lowd, ah flinty hart repent thy crueltie', and the daughter is indeed disfigured. My point is that it is this letter, 'read' by the lady, possibly silently, aurally projecting on to the page or, just as likely aloud since Mouse-slayer is eavesdropping, that initiates her conversion from faithful wife to adulteress. On reading it, this lady seems to discover 'something about herself': her cruelty. In fact, she only thinks she does because she has identified with the fake hard-hearted daughter and the fake suitor. 
When she returns the letter to the bawd, she does so "with much to doo to with holde her swelling tears', expressing sorrow equally for both the daughter and the suitor. ${ }^{52}$

It is not just the lady in the story who is confused by what she reads, however, nor is it only the act of performing that proves complicating. A silent reading that fails to recognise 'voice' is also susceptible. The difficulty of this work is the way in which one voice blurs into another: Streamer's voice is also Mouse-slayer's, which is also the lady's, which is also the fake lover's. All of this is transcribed by 'Baldwin' who tries - not entirely successfully - to bring some order to this multivocal tale, making it look 'book like'. One of the ways he does this is by adding a gloss to key points and moral sayings for the reader. Often the gloss is helpful. Who can disagree with one of the notes on the bawd's tale: 'Evil communication confoundeth good vertues'? This is - or surely should be - the moral of the tale we have just read. However, most of the time 'Baldwin's' gloss is downright misleading, and it adds to the confusion of voices. Indeed, 'Baldwin' often seems oblivious to who is speaking, and as he transcribes, and then edits further, all voices blur into one. Above the marginal note I have just noted is another: 'All extremities are to be forsaken' ${ }^{53}$ In this instance, the saying is excerpted from a speech whose source is the bawd, and she is persuading the virtuous lady that committing adultery is a moral action. How did it come to pass, I ask, that 'Baldwin', so sceptical of prosopopoeia at the start of Streamer's tale, obligingly marks the sayings that are uttered by the bawd (and Mouse-slayer) in the passage below?

Whereupon I gather that though God would have us keep our faith to our husbands yet rather then any should dye for our sakes, we should not make any conscience to save theire lives. For it fareth in this poi[n]t as it doth in all other: for as all extremities are vices: so it is a vice, as apeereth plainly by the punishment of my daughter to be to extream in honesty, chastety, or any other kinde of vertue. ${ }^{54}$ 
Finally, this conundrum is shared by the actual reader of the text. Let's suppose that you read the text aloud, or imagine that you are doing so. After all, 'Baldwin' did boast in his preface that he thinks he has caught Steamer's speaking voice in the text, declaring that the reader may well 'dout whether he speaketh or readeth'. You may indeed share this 'dout' if you attend to the vocal cues on the page of the 1584 edition, printed by Edward Allde, from which I have been quoting. Among these cues I include the text's phonetic spelling: 'throwled' sounds more 'lowe' and 'base', I suggest, than the modern substitution 'trolled' (sang). ${ }^{55}$ We also have 'corde' without the ' $h$ ', 'yung' without the 'o', 'dout' without the 'b', and a sounded ' $\mathrm{w}$ ' in 'continewally' as well as a double 'oo' to lengthen 'do' and a final 'e' to lengthen 'talke' or 'speeke'. (The 'e' at the end of a word, the schoolmaster Richard Mulcaster argues in his discussion of English spelling, lengthens the sound of the vowels in the middle of a word. $)^{56}$ I also include the text's punctuation, added by a compositor in Allde's print shop, which we know was attentive to the pointing of play texts. ${ }^{57}$ In this edition of Beware the Cat, it is the use of the colon to prompt a dramatic pause that I would draw to your attention. We can see how this works in the following sentence delivered by the bawd: 'Within two dayes after my sonne in law her husba[n]d dyed sudainly, and within two dayes after as she sate heer with me lamenting his death: a voice cried alowd, ah flinty hart repent thy crueltie, and immediately (o extreme rigor) she was chaunged as you now see her'. ${ }^{58}$ This dramatic pause, followed by a shorter pause or comma after 'alowd', allows for a shift in voice as the real reader breathes life into the curse by reading it aloud.

What is so curious about Beware the Cat is that there is no way we can avoid being implicated in this multivocal text. Nor can we ignore the fact that our judgement is being clouded just like 'Baldwin's'. This is what is so brilliant about Baldwin's writing: he makes the reader think about how she is being acted on as she reads aloud (or imagines that she is 
doing so). This is the same conundrum, I now want to argue, that Baldwin explores in a collection of tragic histories written a year after Beware the Cat, and which was printed in a 'lightly revised' form in 1559, A Myrroure for Magistrates. ${ }^{59}$

\section{A Myrroure for Magistrates (1559)}

The 1559 Myrroure has two prefaces, both written by Baldwin, probably at different times. Each of them indicates a different way of reading the work, the one silently and studiously, the other aloud. In the first preface, dedicated 'To the nobilitye and all other in office', Baldwin proposes that the purpose of the work is moral-political, and we are advised to 'reade \& marke' the Myrroure's tragic narratives as admonitory examples, noting that bad governors have not 'escaped infamy'. ${ }^{60}$ Some Renaissance readers did read the Myrroure in this way. In one edition, held by the Bodleian Library, wise sayings are either underlined or highlighted with a trefoil in the margin. ${ }^{61}$ However, in the second preface titled 'A Briefe Memorial', Baldwin tells us more about the inception and composition of the work and suggests a different way that it might be read. He relates that he carried to the first meeting of the Myrroure's collaborators a copy of Lydgate's The fall of prynces and that all present agreed that they would have to start afresh since, with Lydgate dead, the 'unfortunate' would need a new listener to 'make their mone' to. He also tells us that they agreed that this new listener should be 'Baldwin' himself:

To make therfore a state mete for the matter, [the collaborators] al agreed that I shoulde usurpe Bochas rowme, and the wretched princes complayne unto me: and tooke upon themselves every man for his parte to be sundrye personages, and in theyr behalfes to bewayle unto me theyr grevous chaunces, hevy destinies, \& wofull misfortunes. ${ }^{62}$ 
This second preface, it is often noted, draws attention in a way that the first preface does not to the unusual dramatic frame that connects the tragedies, in which the collaborators comment on what they have heard ${ }^{63}$ I agree, although I would also note that what it draws attention to first and foremost, and uniquely, is the idea that the fallen protagonists will 'bewayle ... theyr grevous chaunces, hevy destinies, \& wofull misfortunes' in the first person to Baldwin. Each narrative, that is, is delivered orally by its author so that what we are reading - aloud or silently - is imagined as a live performance. In short, the tragedies are an example of what Neil Rhodes calls 'speech-writing' and the Tudor schoolmaster, Richard Rainolde, 'eidolopoeia': an oration 'when a dedde manne talketh'. (This is one of the subgenres of 'ethopoeia' or prosopopeia discussed by Rainolde. ${ }^{64}$ Once we note this, it is difficult to read the Myrroure as straightforwardly admonitory. There is no point in marking a wise saying in the margin, even when we are explicitly invited to do so, unless we also take account of who is saying it and why, and think about how their 'mone' affects us.

I will consider one paradigmatic example, although I pick up the broader implications of this way of reading the Myrroure in my conclusion. My example is the tragedy attributed to Chaloner titled 'Howe kynge Richarde the seconde was for his evyll governaunce deposed from his seat, and miserably murdred in prison'. From its title, it would seem to be an admonitory tale, and indeed it is full of wise sayings. The speaker Richard II addresses 'Baldwin' directly, asking him to 'paynt' his 'vicious story' so that others might learn from it. ${ }^{65}$ Richard dutifully details the vicious things he did while alive. He listened to 'false Flatterers' rather than wise counsellors; he embezzled money raised from his over-taxed subjects; he was a glutton, living high on the hog; and he over-indulged in 'Venus pleasures'. In the annotated copy held by the Bodleian Library, the following sentences - all of them wise - are dutifully underlined: 
Shame sueth sinne, as rayne drops do the thunder.

A king can never imagine ought so bad

But most about him will perfourme it glad.

And whan a man is falne in froward fate

Still mischeves light one in anothers pate:

The last four lines of the final stanza are marked with a trefoil in the margin:

Thus lawles life, to lawles deth ey drawes.

Wherfore byd Kynges be rulde and rule by right,

Who wurketh his wil, \& shunneth wisedomes sawes

In flateries clawes, $\&$ shames foule pawes shal light. ${ }^{66}$

If we take the advice of Baldwin's first preface then this tragedy must be read as admonitory. Considering the time of its composition, we might suppose that the advice given was originally intended for Mary I, although by 1559, when Mary was long dead, it would have offered a more general message for anyone taking up office. ${ }^{67}$ Yet difficulties with this reading remain. How easy is it for us to take Richard II's admonition from the grave when we are listening to him, or rather to 'one of the cumpany', Chaloner, who has elected to 'say sumwhat for king Richard' (my italics), and who invites 'Baldwin' to 'imagine ... that you see him al to be mangled, with blew woundes, lying pale and wanne al naked upon the cold stones in Paules church'? ${ }^{68}$ It is not just that Richard II is a compromised moraliser because 
of the way he lived his life. We hear this moral tale from the 'mouth' of a sympathiser who makes this usurped king both self-pitying and, I would also suggest, pitiable.

Richard II does not just confess his crimes, reminding us what happens to ambitious men unsuited to high office; he also blames those whom he knows have betrayed him. Chaloner - a master of prosopopoeia, as his translation of Moriae Encomium attests - allows Richard II's 'voice' in the text to change almost imperceptibly, so that we move from a confession, in which the speaker lists his failings, to a complaint focussed on this speaker's sense of betrayal. There is another turn in the story which places Richard II's treacherous servants centre stage. They were later 'Abhorde' by the usurper Henry Bolinbroke, leading them to attempt to reinstate Richard II, only to discover how hard this is: 'Thinges hardly mende, byt may be mared amayne' ${ }^{69}$ It is this self-interested rebellion that leads Henry Bolingbroke, now Henry IV, to despatch 'a traytrous knight ... Who causeles kild me there agaynst all lawes' (my italics). ${ }^{70}$ Is this murder a just punishment or an injustice without cause?

We can see just how confusing this admonitory tale is if we look more closely at the sentences highlighted in the Bodleian Library copy as well as the fictional frame which records the views of the collaborators. This reader, whoever he or she was, has noted the moral advice of the tragedy in its last four lines: that kings should be ruled by 'right' However, other annotations signal that this reader is taking a different admonition from the mouth of King Richard: that a ruler cannot trust his servants, and that the turning of fortune's wheel is unstoppable (so one can't get back up again easily). It is as if this reader is unsure whether Richard II is the perpetrator or the victim, and this confusion, I suggest, is shared by the collaborators in the fiction. Having listened to this 'so wofull a tragedy', as one of them puts it, the collaborators pause to reflect on what they will do next since they have 'passed through a miserable time full of piteous tragedyes'. What is striking is that they have been 
rendered a 'silent cumpany', unable to choose the next story to tell. Have they been cast in 'a browne study', 'Baldwin' asks? Have they no 'affeccion' to any of the stories he proposes? We are a long way from the intention of the Myrroure, as set out in the first preface.

To explore this privileging and problematizing of affect I have considered Chaloner's tragedy of Richard II as a paradigmatic example. In reading this tragedy in this way, it has not been my intention to argue that it is neither moral nor political. The commonplace that a king should be ruled by the law is just that: a commonplace. There is no reason to assume that Baldwin would have demurred from this conventional view. What I am suggesting, however, is that a moral and political reading involves much more than the marking of particular content and 'sentences'. It also involves a heightened sensitivity to affect, to the ethos and pathos of a speaker, judged against the life he or she lived. This means 'listening' to Richard II critically, judging what he says alongside the tragedies of his servants. It also means being aware of the effect of the voice on listeners, an effect we have forgotten to look for. 
I would like to thank the Leverhulme Trust who made possible the research for this chapter.

${ }^{1}$ John N. King, 'William Baldwin' in Oxford Dictionary of National Biography,

http://www.oxforddnb.com.libproxy.ncl.ac.uk/view/article/1171?docPos=1, accessed $8^{\text {th }}$ July 2015.

Scott C. Lucas says he died in September 1563 of the plague. See A Mirror for Magistrates: and the

Politics of the English Reformation (Amherst: University of Massachusetts Press, 2009), p. 41. The

source for this claim is John Stow, Brit Lib. MS Harley 367, f.3, printed by Charles L. Kingsford, $A$

Survey of London by John Stow, 1 (Oxford, 1908): xlviii-xlix.

${ }^{2}$ Ibid.

${ }^{3}$ Alex Ryrie, 'Edward Whitchurch', Oxford dictionary of National Biography,

http://www.oxforddnb.com/view/article/29233?docPos=1, last accessed $21^{\text {st }}$ June, 2015. For the claim that Baldwin worked as a 'corrector' see King, 'William Baldwin'.

${ }^{4}$ Lucas, Politics of the English Reformation, p. 18.

${ }^{5}$ William Baldwin, A Myrroure for Magistrates (London, 1559), sig. A1 ${ }^{\mathrm{r}}$; Giovanni Boccaccio, The fall of prynces (London, 1554), verso of title page.

${ }^{6}$ Lucas, Politics of the English Reformation, p. 8.

${ }^{7}$ Baldwin, Myrroure, sig. $\llbracket 2^{\mathrm{r}}$.

${ }^{8}$ Lucas, Politics of the English Reformation, pp. 8-11.

${ }^{9}$ Baldwin, Myrroure, sig. A1 ${ }^{\mathrm{v}}$.

${ }^{10}$ Lucas, Politics of the English Reformation, p. 18.

${ }^{11}$ Ibid., p. 50.

${ }^{12}$ King, 'William Baldwin'.

${ }^{13}$ The Myrrour's first modern editor, privileged the first preface. See L. B. Campbell (ed.), The

Mirror for Magistrates (Cambridge: Cambridge University Press, 1938).

${ }^{14}$ Lucas, Politics of the English Reformation, pp. 181-9.

15 Ibid., pp. 23-35.

${ }^{16}$ William Baldwin, Beware the Cat, ed. William A. Ringler, Jr and Michael Flachmann (San Marino, CA: Huntington Library, 1988), p. xvi. Their source for this information is Albert Feuillerat,

Documents Relating to the Revels at Court in the Time of King Edward VI and Queen Mary (Louvain: Uystpruyst, 1914), pp. 89-125.

${ }^{17}$ Abraham Fraunce, The Arcadian rhetorike (London, 1588), sigs. I2 ${ }^{\mathrm{v}}-\mathrm{I} 3^{\mathrm{r}}$; John Brinsley, Ludus

Literarius: Or, The Grammar Schoole (London, 1612), sigs. 2E2 $2^{\mathrm{v}} 2 \mathrm{E} 3^{\mathrm{r}-\mathrm{v}}$. Henry Peacham, The

Garden of Eloquence Conteyning the Figures of Grammer and Rhetorick (London, 1577), sig. D3 ${ }^{\mathrm{r}}$.

Richard Rainolde, A booke called the Foundacion of Rhetorike (London, 1563), sig. N1 ${ }^{\mathrm{r}-\mathrm{v}}$.

${ }^{18}$ On the role of the corrector see Adrian Johns, The Nature of the Book: Print and Knowledge in the

Making (Chicago: University of Chicago Press, 1998), pp. 90-1. See also Terence N. Bowers, 'The

Production and Communication of Knowledge in William Baldwin's Beware the Cat: Toward A

Typographic Culture', Criticism 33 (1991), 1-29. Bowers' excellent article is attentive to Baldwin's role in Whitchurch's print shop, though his end is different to mine; he explores arguments for increased literacy and the new emphasis on silent reading and reasoning.

${ }^{19}$ Thomas Cranmer, The Boke of common praier and administration of the Sacramentes, and other

Rytes and ceremonies of the Churche, after the use of the churche of Englande (London, 1547), A2v.

${ }^{20}$ Boccaccio, The fall of prynces, sig. $2 \mathrm{G}^{\mathrm{r}}$.

${ }^{21}$ On the way in which prosopopoeia complicates historical-moralizing in the Myrroure see Jennifer

Richards, 'Transforming A Mirror for Magistrates', in Margaret Healy and Tom Healy (eds.),

Renaissance Transformations: The Making of English Writing, 1500-1650, (Edinburgh: Edinburgh

University Press, 2009); Donald Jellerson, 'The Spectral Historiopoetics of the Mirror for

Magistrates', Journal of the Northern Renaissance, 2 (2010), http://www.northernrenaissance.org/the-

spectral-historiopoetics-of-the-mirror-for-magistrates/ Last accessed 23 July 2015.

${ }^{22}$ Heidi Brayman-Hackel, Reading Material in Early Modern England: Print, Gender and Literacy

(Cambridge: Cambridge University Press, 2005), p. 47. 
${ }^{23}$ William Baldwin, A maruelous hystory intitulede, beware the cat, (London, 1584), sigs. A4 ${ }^{\mathrm{r}-\mathrm{v}}$. All citations of Beware the Cat are from this edition, unless otherwise stated.

${ }^{24}$ Ibid., sigs. A $5^{\mathrm{v}}-\mathrm{A} 6^{\mathrm{v}}$.

${ }^{25}$ Ibid., sig. E5 .

${ }^{26}$ Ibid., sig. D5 ${ }^{\mathrm{r}}$.

${ }^{27}$ Ibid., sig. A3 ${ }^{\text {r }}$. See Jane Griffiths, Diverting Authorities: Experimental Glossing Practices in

Manuscript and Print (Oxford: Oxford University Press, 2014), p. 125.

${ }^{28}$ William Baldwin, Beware the Cat: The First English Novel (San Marino, CA: Huntington Library, 1988), pp. xxix-xxx.

${ }^{29}$ Baldwin, A maruelous hystory, sig. A3 ${ }^{\mathrm{v}}$.

${ }^{30}$ Rachel Stenner, 'The Act of Penning in William Baldwin's Beware the Cat', Renaissance Studies (forthcoming), p.000.

${ }^{31}$ John N. King, English Reformation Literature: The Tudor Origins of the Protestant Tradition

(Princeton, N.J.: Princeton University Press, 1982), pp. 397-8. See also Stephen Gresham, 'William

Baldwin: Literary Voice of the Reign of Edward VI', Huntington Library Quarterly 44 (1981), 101 16; Bowers, 'Production and Communication of Knowledge'.

${ }^{32}$ Thomas Betteridge, Literature and Politics in the English Reformation (Manchester: Manchester University Press, 2004), p. 115.

${ }^{33}$ Stenner, 'The Act of Penning', p. 000.

${ }^{34}$ Griffiths, Diverting Authorities, pp. 128-9, 133.

${ }^{35}$ Peter Elbow, 'What Do We Mean When We Talk about Voice in Texts?' in Voices on Voice:

Definitions, Perspectives, Inquiry, ed. Kathleen Blake Yancey (Urbana, IL: National Council of

Teachers of English, 1994, 1-35, pp. 4-5.

${ }^{36}$ Baldwin, A maruelous hystory, sig. A3 ${ }^{\text {r }}$

${ }^{37}$ Ibid., sig. $\mathrm{C}^{\mathrm{v}}$.

${ }^{38}$ Ibid., sigs. $\mathrm{C}^{\mathrm{r}}-\mathrm{C} 3^{\mathrm{r}}$.

${ }^{39}$ Ibid., sigs. C $8^{\mathrm{r}-\mathrm{v}}$.

${ }^{40}$ Ibid., sig. C6 ${ }^{\mathrm{v}}$.

${ }^{41}$ Ibid., sig. C4v

${ }^{42}$ Ibid., sig. C6 ${ }^{\mathrm{v}}$.

${ }^{43}$ Ibid., sigs. C7v .

${ }^{44}$ Ibid., sig. C4 $4^{\mathrm{v}}$.'

${ }^{45}$ C. M. Woolgar, The Senses in Late Medieval England (New Haven: Yale University Press, 2006), p. 84 .

${ }^{46}$ Richard Hooker, Of the lawes of ecclesiasticall politie Eyght bookes, (London, 1593), sig. F2r.

${ }^{47}$ Gavin Alexander, 'Prosopopoeia: The Speaking Figure', in Sylvia Adamson, Gavin Alexander and Katrin Ettenhuber, Renaissance Figures of Speech (Cambridge: Cambridge University Press, 2007), 97-112, p. 105.

${ }^{48}$ Ibid., p. 109.

${ }^{49}$ Ibid., pp. 109-10.

${ }^{50}$ Ibid. sig. E4 ${ }^{\mathrm{r}}$.

${ }^{51}$ Ibid. sig. E2 ${ }^{\mathrm{r}}$.

${ }^{52}$ Ibid., sigs. E2 ${ }^{\mathrm{v}}-\mathrm{E} 3^{\mathrm{r}}$.

${ }^{53}$ Ibid. sig. E3 ${ }^{\mathrm{v}}$.

${ }^{54}$ Ibid. sigs. E3 $3^{\mathrm{r}-\mathrm{v}}$.

${ }^{55}$ For this substitution see Baldwin, Beware the Cat, ed. Ringler and Flachmann, p. 23.

${ }^{56}$ Richard Mulcaster, The First Part of the Elementarie Which Entreateth Chefelie of the right writing of our English tung (London, 1582), sig. O4r.

${ }^{57}$ I. R Burrow, "'The peryod of my blisse": Commas, Ends and Utterance in Solyman and Perseda', Textual Cultures 8.2 (2013): 95-120.

${ }^{58}$ Baldwin, Myrroure, sig. E3 ${ }^{\mathrm{r}}$.

${ }^{59}$ Lucas, Politics of the English Reformation, p. 2,

${ }^{60}$ Baldwin, Myrroure, sigs. $92^{\mathrm{r}}-3^{\mathrm{r}}$.

${ }^{61}$ This is Bodleian Library Wood 328. 
${ }^{62}$ Ibid., sig.A1v

${ }^{63}$ This preface has been commented upon as a means of drawing attention to the use of the frame in the Mirror to stage 'a conversation about power'. See Jessica Winston, 'A Mirror for Magistrates and Public Political Discourse in Elizabethan England', Studies in Philology 101 (2004): 381-400; Sherri Geller, 'Editing Under the Influence of the Standard Textual Hierarchy: Misrepresenting A Mirror for Magistrates in the Nineteenth- and Twentieth-Century Editions', Textual Cultures 2 (2007): 43-77. ${ }^{64}$ Neil Rhodes, Shakespeare and the Origins of English (Oxford: Oxford University Press, 2004), pp. 85-7; Rainolde, Foundacion of Rhetorike, sigs. $\mathrm{N1}^{\mathrm{r}-\mathrm{v}}$.

${ }^{65}$ Baldwin, Myrroure, sig. E3 ${ }^{\mathrm{r}}$.

${ }^{66}$ Ibid., sigs. E2 ${ }^{\mathrm{v}}-\mathrm{F} 1^{\mathrm{r}}$.

${ }^{67}$ Lucas, Politics of the English Reformation, pp. 195-201.

${ }^{68}$ Baldwin, Myrroure, sig. E2 ${ }^{\mathrm{r}}$.

${ }^{69}$ Ibid., sig. E4 ${ }^{\mathrm{r}}$.

${ }^{70}$ Ibid., sig. E4 ${ }^{\mathrm{v}}$. 